\title{
Impact of reduced levels of $A P E 1$ transcripts on the survival of patients with urothelial carcinoma of the bladder
}

\author{
MARIANA CHANTRE-JUSTINO ${ }^{1-3}$, GILDA ALVES ${ }^{2,3}$, CONSTANÇA BRITTO ${ }^{4}$, ANGÉLICA CARDOSO ${ }^{4}$, \\ LUCIANO SCHERRER $^{5}$, ALINE DOS SANTOS MOREIRA ${ }^{6}$, RAUL QUIRINO ${ }^{7}$, \\ ANTONIO ORNELLAS ${ }^{7,8}$, ALVARO LEITÃO ${ }^{1}$ and CLAUDIA LAGE ${ }^{1}$ \\ ${ }^{1}$ Carlos Chagas Filho Institute of Biophysics, Rio de Janeiro Federal University; ${ }^{2}$ Research Coordination, \\ National Institute of Cancer (INCA); ${ }^{3}$ Circulating Biomarkers Laboratory, Department of Pathology, \\ State University of Rio de Janeiro (UERJ); ${ }^{4}$ Molecular Biology and Endemic Diseases Laboratory, \\ Oswaldo Cruz Foundation (FIOCRUZ), Rio de Janeiro; ${ }^{5}$ Brazilian Society of Clinical Oncology, \\ Belo Horizonte, Minas Gerais; ${ }^{6}$ DNA Sequencing Platform, PDTIS/FIOCRUZ; ${ }^{7}$ Department of Urology, \\ National Institute of Cancer; ${ }^{8}$ Department of Urology, Hospital Mário Kröeff, Rio de Janeiro, Brazil
}

Received May 5, 2015; Accepted June 24, 2015

DOI: $10.3892 / o r .2015 .4151$

\begin{abstract}
Molecular evidence indicates that alterations in genes involved in the maintenance of genome stability may be related to susceptibility to bladder carcinoma. Our goal was to evaluate the prognostic role of base excision repair (BER) genes in a cohort of patients diagnosed with primary urothelial carcinoma of the bladder (UCB). The levels of all $A P E 1, X R C C 1$ and $P O L B$ transcripts were detected by quantitative real-time PCR (qPCR) technique in tumor samples from 52 patients undergoing transurethral resection (TUR) for primary UCB at the Department of Urology, Brazilian National Cancer Institute, Rio de Janeiro. Increased levels of $A P E 1, X R C C 1$ and $P O L B$ transcripts were significantly associated with high-grade tumors when compared to these levels in low-grade tumors $(\mathrm{p}<0.01)$ and could be attributed to different mechanisms of transcriptional regulation as a response to tumorigenesis and oxidative stress. By analyzing the collected data in the present study, regardless of pathological grade or stage, univariate analysis revealed that the reduced levels of APE1 transcripts were significantly associated with cancer-specific mortality $(\mathrm{p}=0.032)$. Furthermore, the variant genotype (TG/GG) of the APE1 T1349G polymorphism was observed in $75 \%$ of a subset of patients who concomitantly experienced reduced levels of the APEl transcript and death and/or recurrence events. Taken together, our data reinforce
\end{abstract}

Correspondence to: Dr Mariana Chantre-Justino or Dr Gilda Alves, Circulating Biomarkers Laboratory, Department of Pathology, State University of Rio de Janeiro (UERJ), Av. Prof Manuel de Abreu, 444, $4^{\circ}$ andar, Vila Isabel, Rio de Janeiro 20550-170, Brazil

E-mail: mari.chantre@gmail.com

E-mail: galvesbrown@gmail.com

Key words: bladder cancer, polymorphism, DNA repair, gene expression, quantitative real-time PCR, survival the idea that human DNA repair mechanisms must be finely regulated in order to avoid instability leading to tumorigenesis and poor clinical outcomes in UCB patients.

\section{Introduction}

Urothelial carcinoma of the bladder (UCB) is the second most common genitourinary tumor in men, significantly increasing worldwide cancer statistics. The overall survival rate for bladder cancer recorded for a five-year follow-up period is $\sim 78 \%$ (1). It is a heterogeneous neoplasm of unpredictable clinical course. Approximately $75 \%$ of cases are classified as non-muscle invasive bladder cancer (NMIBC; pTa/pT1 stage) at initial diagnosis. The remaining $25 \%$ of cases consist of tumors displaying the ability of muscular invasion and are classified as muscle invasive bladder cancer (MIBC; pT2-pT4 stage). Genetic studies suggest that the events of initiation, promotion, and progression of UCB can be described by a model based on two distinct molecular alteration patterns showing divergent clinical behavior (2-4). Tobacco smoking and occupational exposure to aromatic amines are considered well-established exogenous risk factors for UCB (5). Furthermore, genetic and epigenetic alterations also contribute to UCB risk (6-9). Thus, interaction between environmental exposure and genetic susceptibility can greatly increase DNA damage and thus trigger urothelial precancerous events; therefore, the prompt elimination of such damage counteracts malignant transformation (10).

DNA repair mechanisms are multistep processes essential for maintaining genomic stability. Distinct DNA repair pathways recognize different types of DNA damage $(11,12)$. The base excision repair (BER) pathway plays a critical role by removing nucleobase modifications by oxidation, alkylation, deamination, and also backbone single-strand DNA (ssDNA) breaks (13). A BER malfunction could thus lead to accumulation of DNA lesions with a direct impact on the risk of tumorigenesis, including UCB (14). The enzyme APE1 has 
a mainframe role in BER by correcting apurinic/apyrimidinic (AP) sites, which are pre-mutagenic lesions able to stall DNA replication forks. Besides its role in DNA repair, APE1 is also a transcriptional regulator of gene expression (15). The protein XRCC1 plays a crucial role in BER. Although no direct catalytic activity has been observed for XRCC1, it operates as a scaffold protein for other BER enzymes $(16,17)$. DNA polymerase $\beta$ (Pol $\beta$ ), a member of the $X$ family DNA polymerases, is the major polymerase in BER due to its $\mathrm{dRP}$ lyase activity and the main gap-filling enzyme (18).

Several molecular markers have been investigated to improve UCB diagnosis and to provide potential therapeutic targets. Gene expression profiling has been used as a strategy to identify molecular subtypes, which could refine the classification of bladder tumors (19-21). However, to date, no analyzed marker has appeared conclusive for clinical practice. The aim of the present study was to investigate whether variations in the levels of transcripts $A P E 1, X R C C 1$ and $P O L B$ could influence the clinical outcomes of patients diagnosed with primary UCB. The analyses were performed by quantitative realtime PCR (qPCR) methodology (22). Our findings suggest a significant correlation between the reduced levels of APE1 transcripts and the poor survival of UCB patients.

\section{Materials and methods}

Patient database. Fifty-two patients diagnosed with primary UCB submitted to transurethral resection (TUR) at the Department of Urology, Brazilian National Cancer Institute, Rio de Janeiro, between 2004 and 2009 were eligible for this study. After TUR, fresh tissue samples were immediately stored in liquid nitrogen until further analysis. This project was approved by the Ethics Committee of the Brazilian National Cancer Institute. At recruitment, informed consent was obtained from each eligible subject. Patient records were accessed to collect the following information: date of registration at the hospital, age at diagnosis, gender, pathological grade and stage, recurrence, and disease-specific mortality (DSM).

The specimens obtained were classified as 25 low-grade papillary urothelial carcinoma and 27 high-grade papillary urothelial carcinoma. Pathological staging consisted of 42 NMIBC specimens (Ta/T1 stage) and 10 MIBC specimens (T2-T4 stage). The study group included 43 men and 9 women with a mean age of 68 years (range 48 to 92). Median follow-up was 55.5 months (range 2 to 101 months). Disease recurred in $51.9 \%$ of all patients (range 1 to 33 months) and $23.1 \%$ died (range 3 to 95 months) of UCB. Table I shows the major clinicopathologic characteristics of the UCB patients in this study.

RNA isolation and cDNA synthesis. Total RNA was isolated from tissue samples using $\mathrm{TRIzol}^{\circledR}$ reagent according to the manufacturer's instructions (Invitrogen, Carlsbad, CA, USA). After the extraction process, all samples were treated with DNase I (RNase-free) [Uniscience, New England Biolabs (NEB), Ipswich, MA, USA] to remove any residual DNA from the previous step. RNA quality was evaluated using $1 \%$ agarose gel electrophoresis in $1 \mathrm{X}$ TBE buffer (Tris-borate-EDTA in DEPC water). Subsequently, RNA quantification was performed on the NanoDrop spectrophotometer (Thermo Scientific, Waltham, MA, USA) and the
Table I. Characteristics of the investigated UCB patients.

\begin{tabular}{lc}
\hline Characteristics & Data \\
\hline No. of patients with primary tumor diagnosis & 52 \\
Mean age (years) & 68 \\
Gender, n (\%) & \\
Female & $9(17)$ \\
Male & $43(83)$ \\
Grade, n (\%) & \\
Low-grade (LG) & $25(48)$ \\
High-grade (HG) & $27(52)$ \\
Stage, n (\%) & \\
Ta/T1 & $42(81)$ \\
T2-T4 & $10(19)$ \\
Follow-up (months) & 55.5 \\
Disease-specific mortality (DSM), n (\%) & \\
Low-grade (LG) & $5(20)$ \\
High-grade (HG) & $7(26)$ \\
Ta/T1 & $7(17)$ \\
T2-T4 & $5(50)$ \\
Recurrence, n (\%) & \\
Low-grade (LG) & $12(48)$ \\
High-grade (HG) & $15(55.6)$ \\
Ta/T1 & $19(45.2)$ \\
T2-T4 & \\
\hline & \\
& \\
&
\end{tabular}

$260 / 280 \mathrm{~nm}$ ratio was measured to obtain RNA purity. Total RNA $(1 \mu \mathrm{g})$ was converted by reverse transcription to cDNA using the SuperScript ${ }^{\mathrm{TM}}$ II reverse transcriptase and random primers (both from Invitrogen), according to the manufacturer's instructions. Following cDNA synthesis, the samples were stored at $-20^{\circ} \mathrm{C}$.

Quantitative real-time PCR analysis. The relative expression of target transcripts was compared with cDNA pools from non-cancerous tissues adjacent to the tumor, which were used as reference samples. Quantitative real-time PCR (qPCR) reactions were performed with $100 \mathrm{ng}$ cDNA samples in uniplex reactions by using a mix of Platinum ${ }^{\circledR} \mathrm{SYBR}^{\circledR}$-Green qPCR SuperMix-UDG (Invitrogen) in Platform Applied Biosystems (ABI PRISM ${ }^{\circledR} 7000$ sequence detection system; Applied Biosystems, Foster City, CA, USA). Details regarding GenBank accession numbers, primer sequences, Tm values, and amplicon length are listed in Table II. The GAPDH gene was used as reference and its expression level was measured in all samples individually to normalize APE1, XRCC1 and $P O L B$ expression. The relative quantification of the results obtained by qPCR was based on the comparative $\mathrm{Ct}$ method $\left(2^{-\Delta \Delta \mathrm{Ct}}\right)$.

The qPCR conditions were conducted as follows: 1 cycle at $50^{\circ} \mathrm{C}(5 \mathrm{~min})$ and $94^{\circ} \mathrm{C}$ ( $\left.3 \mathrm{~min}\right)$ for enzyme activation, followed by 40 cycles at $94^{\circ} \mathrm{C}(45 \mathrm{sec}), 50^{\circ} \mathrm{C}(30 \mathrm{sec}), 72^{\circ} \mathrm{C}(30 \mathrm{sec})$, and a subsequent final extension at $72^{\circ} \mathrm{C}(5 \mathrm{~min})$. Net gene 
Table II. GenBank accession no., primer sequences, amplicon length and the expected Tm value for the qPCR assays.

\begin{tabular}{llllcc}
\hline Gene & \multicolumn{1}{c}{$\begin{array}{c}\text { GenBank } \\
\text { accession no. }\end{array}$} & \multicolumn{1}{c}{$\begin{array}{c}\text { Forward primer } \\
\left(5^{\prime} \rightarrow 3^{\prime}\right)\end{array}$} & $\begin{array}{c}\text { Reverse primer } \\
\left(5^{\prime} \rightarrow 3^{\prime}\right)\end{array}$ & $\begin{array}{c}\text { Amplicon } \\
\text { length }(\mathrm{bp})\end{array}$ & $\begin{array}{c}\text { TM value } \\
\left({ }^{\circ} \mathrm{C}\right)\end{array}$ \\
\hline APE1 & NM_001641 & CAATACTGGTCAGCTCCTTCGG & TCATGCTCCTCATCGCCTATG & 127 & 83 \\
$X R C C 1$ & NM_006297 & GACACTTACCGAAAATGGCGG & GCCATCATTCCCAATGTCCA & 111 & 83 \\
POLB & NM_002690 & CAATGAGTACACCATCCGTCCC & GTTCCCGGTATTTCCACTGGA & 110 & 81 \\
GAPDH & NM_001256799 & GCAAATTCCATGGCACCGT & TCGCCCCACTTGATTTTGG & 106 & 82 \\
\hline
\end{tabular}

$A P E 1$, apurinic/apyrimidinic (AP) endonuclease; XRCC1: X-ray repair cross-complementing protein $1 ; P O L B$, DNA polymerase $\beta ; G A P D H$, glyceraldehyde-3-phosphate dehydrogenase.

expression for each patient was then compared, as a panel, for low- and high-grade bladder tumors.

Genotyping. Genotyping assays to evaluate the APE1 T1349G polymorphism were performed by sequencing cDNA samples. The PCR amplification was carried out in the Veriti ${ }^{\circledR}$ Thermal Cycler (Applied Biosystems) by using the primers 5'-GCTTCGAGCCTGGATTAAGAA-3' (forward) and 5'-GGCCTGCATTAGGTACATATGCT-3' (reverse) to amplify the target fragment of APE1. PCR conditions were $94^{\circ} \mathrm{C}(10 \mathrm{~min})$, followed by 40 cycles of $94^{\circ} \mathrm{C}(45 \mathrm{sec}), 50^{\circ} \mathrm{C}$ (30 sec), and $72^{\circ} \mathrm{C}(30 \mathrm{sec})$, and subsequent final extension at $72^{\circ} \mathrm{C}(5 \mathrm{~min})$. PCR products were purified by using GFX PCR DNA and Gel Band Purification kit (GE Healthcare Life Sciences, Chalfont, UK), according to the manufacturer's instructions. The cDNA sequencing was carried out on the Sequencer 3130 Genetic Analyzer (Applied Biosystems) and the results were analyzed with the Sequencher Program (Gene Codes Corporation, Ann Arbor, MI, USA) using the reference sequence from NCBI (NM_001244249.1).

Statistical analyses. Contingency tables were used to associate UCB tumor grade (low-grade vs. high-grade) and stage (pTa/ pT1 vs. pT2-pT4) with clinical outcomes of recurrence and DSM. The Fisher's exact test was adopted to test the statistical significance of the association between these parameters. Statistical analysis was carried out with statistical program $\mathrm{R}$ (v.2.15.1). The association between tumor grade and stage with expression profile was evaluated by non-parametric Mann-Whitney test with SPSS software (v.17.0). The optimal cut-off point for sensitivity and specificity of the transcripts was estimated by receiver operating characteristic (ROC) curves. Univariable recurrence and survival probabilities were estimated by using the Kaplan-Meier method. Univariable and multivariable Cox regression models addressed time to recurrence and mortality. For all statistical tests, $\mathrm{p}<0.05$ was considered to indicate a statistically significant result.

\section{Results}

Association of APE1, XRCC1 and POLB transcript levels and clinicopathological parameters. All samples from MIBC patients (T2-T4 stage) were also classified as high-grade tumors and are referred to in Fig. 1 as HG5, HG8, HG9, HG10, HG11, HG13, HG22, HG23, HG24, and HG25. As shown in
Table III, APE1, XRCC1 and POLB transcript levels were similar between the NMIBC (Ta/T1) and MIBC (T2-T4) groups and therefore were not associated with stage $(\mathrm{p}>0.05)$.

However, as summarized in Table III, statistical analysis revealed highly significant differences in BER transcript levels between low- and high-grade groups $(\mathrm{p}<0.01)$. In particular, increased levels of $A P E 1, X R C C 1$ and $P O L B$ transcripts were detected in high-grade tumors (Fig. 1 and Table III).

According to Fig. 1, reduced levels of XRCCl transcripts were observed in $92 \%$ of low-grade tumors, followed by APE1 (64\%) and POLB (60\%). In addition, the triple combination of reduced levels of $A P E 1 / X R C C 1 / P O L B$ transcripts was observed in $40 \%$ of this tumor group. With regard to high-grade tumors, high levels of $P O L B$ transcripts were detected in nearly $77 \%$ of these tumors, followed by APE1 $(52 \%)$ and $X R C C 1(52 \%)$. Likewise, our data revealed that $33.3 \%$ of high-grade tumors exhibited combined increased levels of the APE1/XRCC1/POLB transcripts.

By observing the panel displayed in Fig. 1, it can be seen that expression of at least one of the BER genes varied among tumor samples of all UCB patients investigated in the present study, appearing different from the levels detected in the noncancerous samples. These findings place BER gene transcriptional activity as a common genetic alteration in UCB pathogenesis.

Correlation of clinicopathological characteristics with clinical outcomes. To assess whether tumor grade or stage has an influence on clinical outcomes, we investigated the relationship between these parameters. The presence of the first recurrence episode was associated with neither tumor stage nor tumor grade (Table IV). Similarly, there was no association between tumor grade and DSM ( $\mathrm{p}=0.746)$. However, the mortality rate was higher and positively associated with advanced pathological stage $(\mathrm{p}=0.039)$.

Regarding the overall survival rate recorded at two and five years after diagnosis, no significant difference between lowand high-grade groups was observed $(\mathrm{p}=0.596$, Table IV). However, MIBC patients had significantly shorter overall survival compared with the NMIBC patients $(p=0.013)$. In relation to recurrence-free survival, we did not observe a significant difference between tumor grade or stage $(\mathrm{p}>0.05)$.

Association of reduced levels of APE1 with cancer-specific mortality. The levels of APE1, XRCC1 and POLB transcripts 


\begin{tabular}{lccccccc}
\hline \multicolumn{3}{c}{ Low-grade (LG) } & \multicolumn{4}{c}{ High-grade (HG) } \\
\hline Cases & $\begin{array}{c}\text { Expression values of } \\
\text { transcripts }\end{array}$ & Cases & \multicolumn{3}{c}{$\begin{array}{c}\text { Expression values of } \\
\text { transcripts }\end{array}$} \\
\hline & APE1 & NRCCI & POLB & & APE1 & XRCCI & POLB \\
\hline LG 1 & 2.07 & 0.11 & 0.27 & HG 1 & 4.87 & 3.55 & 4.14 \\
\hline LG 2 & 1.85 & 0.20 & 0.33 & HG 2 & 3.27 & 2.50 & 2.90 \\
\hline LG 3 & 1.70 & 0.30 & 0.97 & HG 3 & 1.52 & 4.67 & 2.58 \\
\hline LG 4 & 0.79 & 0.24 & 0.40 & HG 4 & 2.13 & 1.31 & 0.33 \\
\hline LG 5 & 1.03 & 0.13 & 0.57 & HG 5 & 1.12 & 0.30 & 2.97 \\
\hline LG 6 & 0.61 & 0.19 & 0.13 & HG 6 & 2.16 & 0.58 & 2.13 \\
\hline LG 7 & 0.85 & 0.22 & 0.77 & HG 7 & 1.75 & 0.80 & 2.27 \\
\hline LG 8 & 0.61 & 0.19 & 0.33 & HG 8 & 0.10 & 1.80 & 0.62 \\
\hline LG 9 & 0.51 & 0.19 & 0.57 & HG 9 & 1.63 & 1.44 & 1.73 \\
\hline LG 10 & 0.37 & 0.51 & 0.30 & HG 10 & 1.44 & 0.58 & 3.27 \\
\hline LG 11 & 0.43 & 1.70 & 0.73 & HG 11 & 1.28 & 0.38 & - \\
\hline LG 12 & 0.65 & 0.29 & 0.27 & HG 12 & 0.84 & 0.61 & 1.05 \\
\hline LG 13 & 1.83 & 0.85 & 0.86 & HG 13 & 4.85 & 2.36 & 1.35 \\
\hline LG 14 & 0.17 & 0.09 & 0.80 & HG 14 & 2.00 & 1.82 & 5.31 \\
\hline LG 15 & 0.53 & 0.21 & 0.40 & HG 15 & 2.09 & 2.18 & 2.70 \\
\hline LG 16 & 0.61 & 0.20 & 0.74 & HG 16 & 0.15 & 0.13 & 0.62 \\
\hline LG 17 & 0.04 & 0.33 & 1.55 & HG 17 & 0.51 & 0.69 & 2.48 \\
\hline LG 18 & 0.45 & 0.26 & 0.63 & HG 18 & 0.29 & 0.49 & 1.66 \\
\hline LG 19 & 0.61 & 0.17 & 0.52 & HG 19 & 0.81 & 2.02 & 3.64 \\
\hline LG 20 & 0.35 & 0.40 & 0.16 & HG 20 & 1.10 & 0.64 & 1.39 \\
\hline LG 21 & 0.36 & 0.26 & 1.17 & HG 21 & 0.85 & 4.03 & 1.30 \\
\hline LG 22 & 0.43 & 0.25 & 0.61 & HG 22 & 1.68 & 0.63 & 3.10 \\
\hline LG 23 & 0.73 & 0.33 & 0.93 & HG 23 & 0.21 & 0.18 & 0.33 \\
\hline LG 24 & 0.49 & 0.10 & 2.07 & HG 24 & 0.98 & 1.06 & 1.70 \\
\hline LG 25 & 0.90 & 0.05 & 0.13 & HG 25 & 0.50 & 2.48 & 0.54 \\
\hline & & & & HG 26 & 3.38 & 2.71 & 3.14 \\
\hline & & & & HG 27 & 2.74 & 1.49 & 2.77 \\
\hline
\end{tabular}

Figure 1. Panel of variations in transcripts levels for APE1, XRCC1 and POLB in low- and high-grade bladder tumors. The levels of all transcripts were normalized against GAPDH levels. Ratios $<0.70$ indicate reduced levels and are highlighted in green; ratios of 0.70-1.29 are in gray and represent similar levels to reference samples; ratios $\geq 1.30$ are in red and show elevated levels. The symbol (-) represents a transcript not analyzed due to insufficient quantity of sample from patient HG11. The cut-off values of transcripts levels were arbitrarily chosen at $30 \%$ above or below the levels of normal mucosa adjacent to the tumor. $A P E 1$, apurinic/apyrimidinic (AP) endonuclease; XRCC1: X-ray repair cross-complementing protein $1 ; P O L B$, DNA polymerase $\beta$.

Table III. Median variation in transcript levels in each UCB group.

\begin{tabular}{|c|c|c|c|c|c|c|}
\hline \multirow[b]{2}{*}{ Transcripts } & \multicolumn{2}{|c|}{$\begin{array}{l}\text { Median value of transcript } \\
\text { expression }\end{array}$} & \multirow[b]{2}{*}{ P-value } & \multicolumn{2}{|c|}{$\begin{array}{l}\text { Median value of transcript } \\
\text { expression }\end{array}$} & \multirow[b]{2}{*}{ P-value } \\
\hline & $\begin{array}{l}\text { Low-grade } \\
\qquad(\mathrm{n}=25)\end{array}$ & $\begin{array}{l}\text { High-grade } \\
\quad(n=27)\end{array}$ & & $\begin{array}{l}\text { Ta/T1 stage } \\
\quad(n=10)\end{array}$ & $\begin{array}{l}\text { T2-T4 stage } \\
\quad(\mathrm{n}=42)\end{array}$ & \\
\hline$A P E 1$ & 0.61 & 1.44 & $0.005^{\mathrm{a}}$ & 1.18 & 1.38 & 0.745 \\
\hline$X R C C 1$ & 0.22 & 1.31 & $0.000^{\mathrm{a}}$ & 0.90 & 1.12 & 0.150 \\
\hline$P O L B$ & 0.57 & 2.20 & $0.000^{\mathrm{a}}$ & 1.35 & 1.73 & 0.235 \\
\hline
\end{tabular}

${ }^{a} \mathrm{p}<0.01$ represents a significant difference. $A P E 1$, apurinic/apyrimidinic (AP) endonuclease; $X R C C 1, \mathrm{X}$-ray repair cross-complementing protein $1 ; P O L B$, DNA polymerase $\beta$.

were compared with the selected clinical outcomes (DSM or recurrence) in each tumor grade and stage group to assess predictive value. Overall, no significant correlation was observed between transcript levels and DSM or recurrence, in either pathological grade or stage (data not shown). Despite that, by analyzing all patients in the study regardless of tumor stage or grade, univariable analysis revealed that reduced levels of APE1 transcripts were significantly associated with DSM ( $\mathrm{p}=0.032$, Fig. 2). According to the ROC plot, specificity and sensitivity for the APEl gene were, respectively, $60 \%$ and
75\%. Therefore, these results revealed that APE1 expression may be an indicator of poor prognosis in UCB patients.

APE1 T1349G polymorphism. Genotyping assays to evaluate the APE1 T1349G polymorphism were performed by preferentially sequencing the cDNA samples from a subset of patients who concomitantly presented reduced levels of APE1 transcripts and death and/or recurrence events (Fig. 3). As summarized in Table $\mathrm{V}$, the $\mathrm{G}$ allele variant was observed in $75 \%(9 / 12)$ of this subset, being present in $67 \%$ (6/9) among 
Table IV. Correlation of the pathological grade and stage with overall survival and recurrence-free survival in the UCB patients.

\begin{tabular}{|c|c|c|c|c|c|c|c|}
\hline \multirow[b]{2}{*}{ Parameters } & \multicolumn{2}{|c|}{ Grade } & \multirow[b]{2}{*}{$\mathrm{P}$-value } & \multirow[b]{2}{*}{ Parameters } & \multicolumn{2}{|c|}{ Stage } & \multirow[b]{2}{*}{ P-value } \\
\hline & $\begin{array}{l}\text { Low-grade } \\
\qquad(n=25)\end{array}$ & $\begin{array}{l}\text { High-grade } \\
\quad(n=27)\end{array}$ & & & $\begin{array}{l}\mathrm{Ta} / \mathrm{T} 1 \\
(\mathrm{n}=42)\end{array}$ & $\begin{array}{l}\text { T2-T4 } \\
(\mathrm{n}=10)\end{array}$ & \\
\hline $\begin{array}{l}\text { First recurrence, n (\%) } \\
\text { episode }^{\mathrm{a}}\end{array}$ & $12(48)$ & $15(55.6)$ & 0.786 & $\begin{array}{l}\text { First recurrence, n (\%) } \\
\text { episode }^{\mathrm{a}}\end{array}$ & $19(45.2)$ & $8(80)$ & 0.078 \\
\hline $\mathrm{DSM}^{\mathrm{a}}, \mathrm{n}(\%)$ & $5(20)$ & $7(25.9)$ & 0.746 & $\mathrm{DSM}^{\mathrm{a}}, \mathrm{n}(\%)$ & $7(16.7)$ & $5(50)$ & $\mathbf{0 . 0 3 9} 9^{c}$ \\
\hline Overall survival rate ${ }^{b}$ & & & & Overall survival rate ${ }^{\mathrm{b}}$ & & & \\
\hline 2-year & $95.2 \%$ & $77.3 \%$ & 0.596 & 2-year & $92.3 \%$ & $57.1 \%$ & $0.013^{c}$ \\
\hline 5-year & $78.1 \%$ & $73.2 \%$ & & 5-year & $82.9 \%$ & $45.7 \%$ & \\
\hline Recurrence-free survival $^{\text {b }}$ & & & & Recurrence-free survival $^{\mathrm{b}}$ & & & \\
\hline 2-year & $95.2 \%$ & $85 \%$ & 0.457 & 1-year & $31.6 \%$ & $25 \%$ & 0.585 \\
\hline 5-year & $65.1 \%$ & $63.6 \%$ & & 2-year & $10.5 \%$ & $12.5 \%$ & \\
\hline
\end{tabular}

${ }^{a}$ The Chi-square test was adopted to test the statistical significance of the association between these variables. ${ }^{\mathrm{b}}$ Statistical differences evaluated by the log rank test. ${ }^{\mathrm{C}}<0.05$ represents a significant difference. $\mathrm{DSM}$, disease-specific mortality.

A

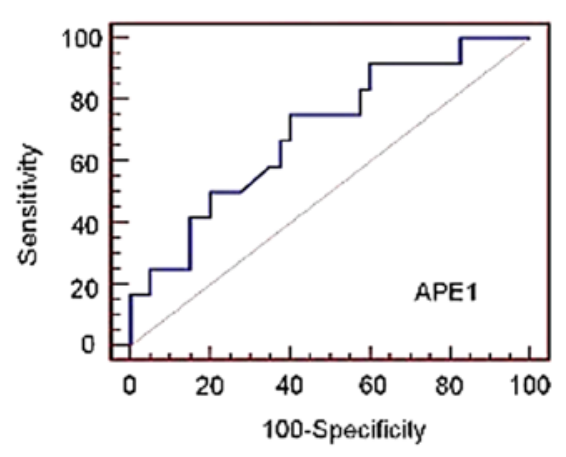

B

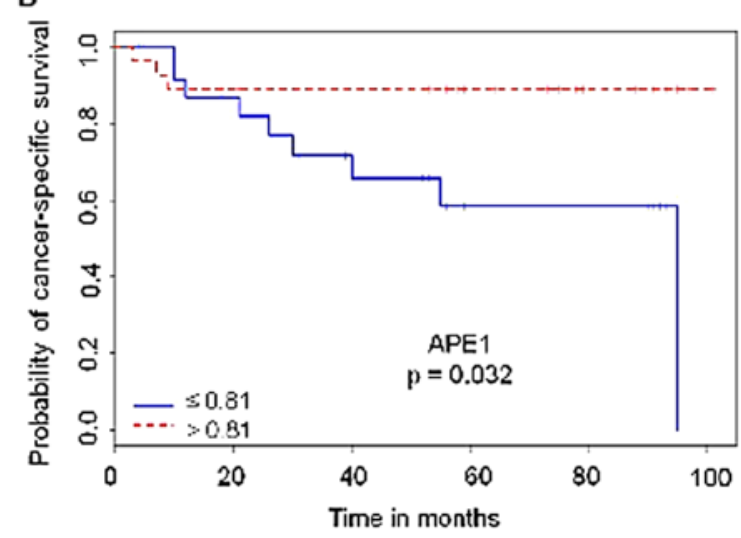

Figure 2. Probability of bladder cancer-specific mortality relatively to APE1. (A) Receiver operating characteristic (ROC) curve for APE1 levels in all UCB patients achieved $75 \%$ sensitivity and $60 \%$ specificity. The optimal cut-off value was 0.81 and the calculated area under the curve (AUC) was 0.697 (95\% CI 0.554-0.817). (B) Kaplan-Meier survival curves depicting cancer-specific survival (\%) of bladder cancer patients for APE1 (red line, altered when combined score was $>0.81$ ). APE1, apurinic/apyrimidinic (AP) endonuclease.

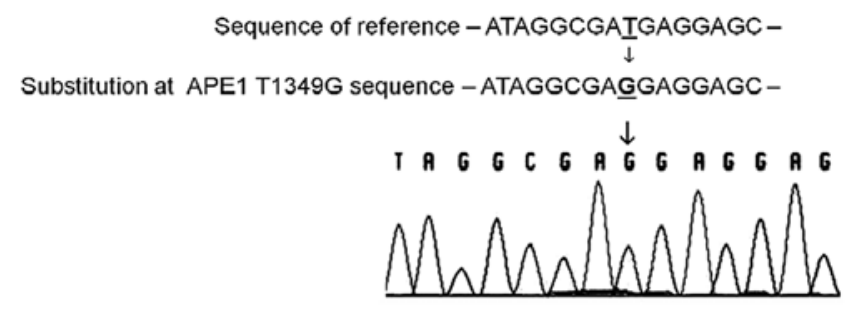

Figure 3. APE1 T1349G polymorphism in the UCB patients. Representative chromatogram of the sense sequence from patient LG19 showing the T to G transversion at APE1 T1349G, as indicated by arrows.

the low-grade cases analyzed. In addition, the variant genotype (TG/GG) was found in $80 \%$ (4/5) of the low-grade cases, whose outcome was either death and/or recurrence. All highgrade patients analyzed had variant genotype (TG/GG), while only individuals with the variant genotypes TG (T2-T4 stage) succumbed to the disease.

\section{Discussion}

Urothelial carcinoma of the bladder (UCB) is a heterogeneous disease comprising multiple and complex molecular changes associated with initiation and tumor progression. Previous indications that pro-oxidant status appears to play a role in 
Table V. Genotype frequencies of the APE1 T1349G polymorphism among the UCB patients.

\begin{tabular}{|c|c|c|c|c|c|c|}
\hline \multirow[b]{2}{*}{ Genotype } & \multicolumn{3}{|c|}{ Low-grade (LG), n=9 } & \multicolumn{3}{|c|}{ High-grade $(\mathrm{HG}), \mathrm{n}=3$} \\
\hline & $\mathrm{n}(\%)$ & Death & Recurrence & $\mathrm{n}(\%)$ & Death & Recurrence \\
\hline TT & $3(33)$ & LG17 & LG17 & $0(0)$ & - & - \\
\hline TG & $3(33)$ & LG23 & LG23 & $2(67)$ & HG8; HG23 & HG8 \\
\hline GG & $3(33)$ & LG11; LG19; LG22 & LG11; LG19; LG22 & $1(33)$ & - & HG17 \\
\hline
\end{tabular}

genitourinary carcinogenesis and its correlation with tumor invasion and metastasis encouraged our team to screen for molecular markers of genetic stability as an attempt to improve UCB prognosis $(23,24)$. DNA repair mechanisms act as a barrier to prevent genetic instability and cancer susceptibility. A few studies have evaluated the association between dysfunction/dysregulation in particular DNA repair genes and UCB risk $(25,26)$. Since APE1, XRCC1 and POLB proteins operate downstream the same DNA repair pathway to eliminate DNA oxidative damage, their expression above basal levels found in our study could reveal excessive oxidative stress in high-grade bladder tumors.

$\mathrm{XRCC1}$ protein is required for efficient DNA repair of other BER-involved enzymes. Notwithstanding its core interplay in BER, a recent meta-analysis did not associate a dysfunctional $X R C C 1$ polymorphism to UCB risk (27). Increased levels of $X R C C 1$ transcripts were also associated with chemoresistance to cisplatin in non-small cell lung cancer (28). The set of results presented in this study revealed that $X R C C 1$ transcripts were increased in 52\% of high-grade tumors, whereas $92 \%$ of low-grade tumors displayed reduced levels of $X R C C 1$. Since single nucleotide polymorphisms (SNPs) cannot be ascribed to such status, transcriptional alterations for $X R C C 1$ were revealed in this study to better characterize the histopathological grade.

In higher eukaryotes, DNA polymerases participate in replication, repair and recombination. Pol $\beta$ is the major BER DNA polymerase. Pol $\beta$ is minimally expressed in normal cells but has been shown to be overexpressed in different tumors both at the transcriptional and protein levels, including bladder tumors (29). Approximately $30 \%$ of all human tumors express variant Pol $\beta$ (30). As previously described in other studies, Pol $\beta$ destabilization plays an important role in disrupting cell cycle control and increasing mutation rates. Being an error-prone DNA polymerase, excess Pol $\beta$ could disturb the processivity of replication forks and increase genetic instability and tumorigenesis by curtailing the activity of error-free DNA polymerases during replication $(31,32)$. Furthermore, Pol $\beta$ can also enhance mutagenesis by incorporation of ribonucleotides into DNA and by competition with replicative DNA polymerases $(33,34)$. Our results revealed that the $P O L B$ transcripts had increased levels in $\sim 77 \%$ of high-grade tumors, suggesting a strong correlation of $P O L B$ dysregulation with tumorigenesis and progression events.

APE1 is a multifunctional protein essential in BER and a redox transcriptional co-activator. APE1 participates in the initial steps of BER by recognizing and nicking potentially genotoxic and mutagenic abasic (AP) sites in different substrates, such as double-strand DNA, hybrid DNA/RNA and RNA molecule (35). APE1 elevated levels have been reported to occur in a group of tumors (36-38). In general, its increased levels provide resistance to chemotherapeutic drugs and ionizing radiation and, as expected, marked cisplatin sensitivity was observed to occur in vitro in tumor cells knocked out for APE1 $(39,40)$. Nonetheless, Sak et al reported that increased APE1 protein levels were correlated with improved cancer-specific survival in patients with muscle-invasive bladder cancer following radical radiotherapy (41). In the present study, reduced APEl levels at initial diagnosis were significantly associated with poor clinical outcome, regardless of the chosen therapeutical approach, pathological grade, or stage. Moreover, reduced levels of APE1 also compromise the regulation of p53 target genes through its redox activity and may result in extensive genomic instability. All of these factors could explain why reduced levels of APE1 transcripts resulted in poorer UCB patient survival, causing it to be an important gene for clinical cancer-specific survival prediction.

In our study, differences in clinical outcomes such as recurrence and DSM were not correlated with pathological grade. However, we identified higher mortality rates and reduced overall survival in patients with advanced tumor stage. Since all MIBC patients analyzed were also designated as highgrade tumors, the characteristic highly aggressive profile of these tumors could explain the increased mortality and poor survival in this subset of UCB patients. The comprehensive profiling of BER transcripts in each pathological grade group highlights meaningful differences in the molecular signature of low- and high-grade bladder tumors that could be attributed to differential transcriptional regulation ensued by tumorigenesis and oxidative stress. Therefore, these differences in BER transcript levels able to characterize two distinct histologic UCB groups found in our study could complement molecular data from previous studies associating low- and high-grade UCB groups with distinct genetic alteration patterns (2-4). Moreover, APE1 analyses presented good specificity and sensitivity parameters (60\% specificity and $75 \%$ sensitivity) which represent important information for a suitable clinical test.

In carcinogenesis events, the most extensively studied polymorphism in the APE1 gene is the T to $\mathrm{G}$ transversion (T1349G, also known as Asp148Glu, rs3136820) (42). Functional studies on this polymorphism have shown that the $G$ variant allele may have an impact on APE1 endonuclease and reduce the ability to communicate with other BER proteins (43). In our study, some patients with reduced levels of APE1 transcripts also experienced death and/or recurrence 
events. In this context, we performed an additional analysis to investigate the presence of the APE1 T1349G polymorphism from this group of patients. Our data pointed out that all high-grade patients analyzed had variant genotypes (TG/ GG), but only individuals with genotype TG (T2-T4 stage) succumbed to the disease. With regard to the low-grade group, the $\mathrm{G}$ allele variant occurred in $80 \%$ (4/5) of the cases, whose outcome was mortality and/or recurrence events. In a study for functional characterization of polymorphisms in DNA repair genes and chromosome aberrations by using X-rays or ultraviolet (UV) light to irradiate blood lymphocytes, samples from individuals with the TG or GG genotype showed higher levels of damage, including aberrant cells, chromatid breaks, chromatid exchanges, deletions, and dicentrics (44). A metaanalysis study showed that individuals carrying at least one $G$ allele were associated with a higher cancer risk than subjects with the TT genotype (45). However, a meta-analysis study performed in 2013 suggested that the APE1 T1349G polymorphism was not associated with bladder cancer risk among Asians or non-Asians (46). Consistent with these observations, our data suggest that besides interfering with APE1 enzymatic activity, as shown in other studies, the $\mathrm{G}$ allele may also modify the APE1 transcriptional levels and result in worse clinical outcome for bladder cancer patients. Our small sample size for this polymorphism analysis $(n=9$ for low-grade and $n=3$ for high-grade groups) should be interpreted with caution, as more detailed data are needed to verify these findings. However, taken together, our results indicate that APE1 is an attractive candidate gene to open new perspective studies for evaluating clinical outcomes of UCB patients. Further analyses are required to validate $A P E 1$ as a reliable predictive molecular marker for UCB.

Finally, the present study thus reinforces the notion that DNA repair gene expression must be finely tuned in order to avoid genetic instability and the process of tumorigenesis (47). Despite current effective treatments to ensure better results for UCB patients, diagnostic and prognostic exams are still partially accurate and should be complemented with auxiliary tests. Therefore, more clinical research on UCB should be encouraged to allow a significant increase in clinical data, better comprehension of the biology of the disease, and optimization of diagnostic and prognostic tests (48).

In conclusion, evaluation of DNA repair transcripts revealed that high-grade tumors exhibited elevated levels of APE1, XRCC1, and POLB as compared with low-grade tumors. Taken together, this panel adds information on the histopathology of bladder tumors. By analyzing all patients, only $A P E 1$ reduced levels were an independent predictor of cancerspecific mortality in primary UCB regardless of pathological grade or stage, and $A P E 1$ may represent a possible candidate gene for evaluating clinical outcomes in UCB. Despite this, evidence suggests that dysregulated BER transcription may promote bladder carcinogenesis.

\section{Acknowledgements}

The authors acknowledge all participing clinicians, investigators, patients, and everyone who encouraged this study. This study was supported by the Brazilian Development Agencies: CAPES, FAPERJ and Prog. Oncobiologia FAF/Onco III.

\section{References}

1. Siegel R, Naishadham D and Jemal A: Cancer statistics, 2013. CA Cancer J Clin 63: 11-30, 2013.

2. Knowles MA: Molecular subtypes of bladder cancer: Jekyll and Hyde or chalk and cheese? Carcinogenesis 27: 361-373, 2006

3. DeGraff DJ, Cates JM, Mauney JR, Clark PE, Matusik RJ and Adam RM: When urothelial differentiation pathways go wrong: Implications for bladder cancer development and progression. Urol Oncol 31: 802-811, 2013.

4. Castillo-Martin M, Domingo-Domenech J, Karni-Schmidt O, Matos T and Cordon-Cardo C: Molecular pathways of urothelial development and bladder tumorigenesis. Urol Oncol 28: 401-408, 2010.

5. Burger M, Catto JW, Dalbagni G, Grossman HB, Herr H, Karakiewicz P, Kassouf W, Kiemeney LA, La Vecchia C, Shariat $\mathrm{S}$, et al: Epidemiology and risk factors of urothelial bladder cancer. Eur Urol 63: 234-241, 2013.

6. Kim WJ and Bae SC: Molecular biomarkers in urothelial bladder cancer. Cancer Sci 99: 646-652, 2008.

7. Shariat SF, Tokunaga H, Zhou J, Kim J, Ayala GE, Benedict WF and Lerner SP: p53, p21, pRB, and p16 expression predict clinical outcome in cystectomy with bladder cancer. J Clin Oncol 22: 1014-1024, 2004

8. Yang J, Xu Z, Li J, Zhang R, Zhang G, Ji H, Song B and Chen Z: XPC epigenetic silence coupled with p53 alteration has a significant impact on bladder cancer outcome. J Urol 184: 336-343, 2010.

9. Yan C, Kim YW, Ha YS, Kim IY, Kim YJ, Yun SJ, Moon SK, Bae SC and Kim WJ: RUNX3 methylation as a predictor for disease progression in patients with non-muscle-invasive bladder cancer. J Surg Oncol 105: 425-430, 2012.

10. Hoeijmakers JH: Genome maintenance mechanisms for preventing cancer. Nature 411: 366-374, 2001.

11. Christmann M, Tomicic MT, Roos WP and Kaina B: Mechanisms of human DNA repair: An update. Toxicology 193: 3-34, 2003.

12. Wood RD, Mitchell M and Lindahl T: Human DNA repair genes, 2005. Mutat Res 577: 275-283, 2005.

13. Zharkov DO: Base excision DNA repair. Cell Mol Life Sci 65: 1544-1565, 2008.

14. Figueroa JD, Malats N, Real FX, Silverman D, Kogevinas M, Chanock S, Welch R, Dosemeci M, Tardón A, Serra C, et al: Genetic variation in the base excision repair pathway and bladder cancer risk. Hum Genet 121: 233-242, 2007.

15. Fritz G: Human APE/Ref-1 protein. Int J Biochem Cell Biol 32: 925-929, 2000

16. Kubota Y, Nash RA, Klungland A, Schär P, Barnes DE and Lindahl T: Reconstitution of DNA base excision-repair with purified human proteins: Interaction between DNA polymerase beta and the XRCC1 protein. EMBO J 15: 6662-6670, 1996.

17. Campalans A, Marsin S, Nakabeppu Y, O'connor TR, Boiteux S and Radicella JP: XRCC1 interactions with multiple DNA glycosylases: A model for its recruitment to base excision repair. DNA Repair (Amst) 4: 826-835, 2005.

18. Allinson SL, Dianova II and Dianov GL: DNA polymerase beta is the major dRP lyase involved in repair of oxidative base lesions in DNA by mammalian cell extracts. EMBO J 20: 6919-6926, 2001.

19. Dyrskjøt L, Thykjaer T, Kruhøffer M, Jensen JL, Marcussen N, Hamilton-Dutoit S, Wolf $\mathrm{H}$ and Orntoft TF: Identifying distinct classes of bladder carcinoma using microarrays. Nat Genet 33: 90-96, 2003.

20. Mengual L, Burset M, Ars E, Lozano JJ, Villavicencio H, Ribal MJ and Alcaraz A: DNA microarray expression profiling of bladder cancer allows identification of noninvasive diagnostic markers. J Urol 182: 741-748, 2009.

21. Damrauer JS, Hoadley KA, Chism DD, Fan C, Tiganelli CJ, Wobker SE, Yeh JJ, Milowsky MI, Iyer G, Parker JS, et al: Intrinsic subtypes of high-grade bladder cancer reflect the hallmarks of breast cancer biology. Proc Natl Acad Sci USA 111: 3110-3115, 2014

22. Bustin SA, Benes V, Garson JA, Hellemans J, Huggett J, Kubista M, Mueller R, Nolan T, Pfaffl MW, Shipley GL, et al: The MIQE guidelines: Minimum information for publication of quantitative real-time PCR experiments. Clin Chem 55: 611-622, 2009.

23. Gecit I, Aslan M, Gunes M, Pirincci N, Esen R, Demir H and Ceylan K: Serum prolidase activity, oxidative stress, and nitric oxide levels in patients with bladder cancer. J Cancer Res Clin Oncol 138: 739-743, 2012. 
24. Kumar B, Koul S, Khandrika L, Meacham RB and Koul HK: Oxidative stress is inherent in prostate cancer cells and is required for aggressive phenotype. Cancer Res 68: 1777-1785, 2008.

25. Michiels S, Laplanche A, Boulet T, Dessen P, Guillonneau B, Méjean A, Desgrandchamps F, Lathrop M, Sarasin A and Benhamou S: Genetic polymorphisms in 85 DNA repair genes and bladder cancer risk. Carcinogenesis 30: 763-768, 2009.

26. Narter KF, Ergen A, Agaçan B, Görmüs U, Timirci O, Isbir T: Bladder cancer and polymorphisms of DNA repair genes (XRCC1, XRCC3, XPD, XPG, APE1, hOGG1). Anticancer Res 29:1389-1393, 2009.

27. Zhuo W, Zhang L, Cai L, Zhu B and Chen Z: XRCC1 Arg399Gln polymorphism and bladder cancer risk: Updated meta-analyses based on 5767 cases and 6919 controls. Exp Biol Med (Maywood) 238: 66-76, 2013.

28. Weaver DA, Crawford EL, Warner KA, Elkhairi F, Khuder SA and Willey JC: ABCC5, ERCC2, XPA and XRCC1 transcript abundance levels correlate with cisplatin chemoresistance in non-small cell lung cancer cell lines. Mol Cancer 4: 18, 2005

29. Albertella MR, Lau A and O'Connor MJ: The overexpression of specialized DNA polymerases in cancer. DNA Repair (Amst) 4: 583-593, 2005

30. Starcevic D, Dalal S and Sweasy JB: Is there a link between DNA polymerase beta and cancer? Cell Cycle 3: 998-1001, 2004.

31. Osheroff WP, Jung HK, Beard WA, Wilson SH and Kunkel TA: The fidelity of DNA polymerase beta during distributive and processive DNA synthesis. J Biol Chem 274: 3642-3650, 1999.

32. Bergoglio V, Pillaire MJ, Lacroix-Triki M, Raynaud-Messina B, Canitrot Y, Bieth A, Garès M, Wright M, Delsol G, Loeb LA, et al: Deregulated DNA polymerase beta induces chromosome instability and tumorigenesis. Cancer Res 62: 3511-3514, 2002.

33. Bergoglio V, Ferrari E, Hübscher U, Cazaux C and Hoffmann JS: DNA polymerase beta can incorporate ribonucleotides during DNA synthesis of undamaged and CPD-damaged DNA. J Mol Biol 331: 1017-1023, 2003.

34. Pillaire MJ, Betous R, Conti C, Czaplicki J, Pasero P, Bensimon A, Cazaux C and Hoffmann JS: Upregulation of error-prone DNA polymerases beta and kappa slows down fork progression without activating the replication checkpoint. Cell Cycle 6: 471-477, 2007.

35. Berquist BR, McNeill DR and Wilson DM III: Characterization of abasic endonuclease activity of human Apel on alternative substrates, as well as effects of ATP and sequence context on AP site incision. J Mol Biol 379: 17-27, 2008.

36. Bobola MS, Blank A, Berger MS, Stevens BA and Silber JR: Apurinic/apyrimidinic endonuclease activity is elevated in human adult gliomas. Clin Cancer Res 7: 3510-3518, 2001.
37. Kelley MR, Cheng L, Foster R, Tritt R, Jiang J, Broshears J and Koch M: Elevated and altered expression of the multifunctional DNA base excision repair and redox enzyme Ape1/ref-1 in prostate cancer. Clin Cancer Res 7: 824-830, 2001.

38. Moore DH, Michael H, Tritt R, Parsons SH and Kelley MR: Alterations in the expression of the DNA repair/redox enzyme APE/ref-1 in epithelial ovarian cancers. Clin Cancer Res 6: 602-609, 2000.

39. Robertson KA, Bullock HA, Xu Y, Tritt R, Zimmerman E, Ulbright TM, Foster RS, Einhorn LH and Kelley MR: Altered expression of Ape1/ref-1 in germ cell tumors and overexpression in NT2 cells confers resistance to bleomycin and radiation. Cancer Res 61: 2220-2225, 2001.

40. Zhang Y, Wang J, Xiang D, Wang D and Xin X: Alterations in the expression of the apurinic/apyrimidinic endonuclease-1/redox factor-1 (APE1/Ref-1) in human ovarian cancer and indentification of the therapeutic potential of APE1/Ref-1 inhibitor. Int J Oncol 35: 1069-1079, 2009.

41. Sak SC, Harnden P, Johnston CF, Paul AB and Kiltie AE: APE1 and XRCC1 protein expression levels predict cancer-specific survival following radical radiotherapy in bladder cancer. Clin Cancer Res 11: 6205-6211, 2005.

42. Gu D, Wang $M$, Wang S, Zhang Z and Chen J: The DNA repair gene APE1 T1349G polymorphism and risk of gastric cancer in a Chinese population. PLoS One 6: e28971, 2011.

43. Hadi MZ, Coleman MA, Fidelis K, Mohrenweiser HW and Wilson DM III: Functional characterization of Ape1 variants identified in the human population. Nucleic Acids Res 28: 3871-3879, 2000

44. Au WW, Salama SA and Sierra-Torres CH: Functional characterization of polymorphisms in DNA repair genes using cytogenetic challenge assays. Environ Health Perspect 111: 1843-1850, 2003

45. Gu D, Wang M, Wang M, Zhang Z and Chen J: The DNA repair gene APE1 T1349G polymorphism and cancer risk: A meta-analysis of 27 case-control studies. Mutagenesis 24: 507-512, 2009.

46. Liu C, Yin Q, Li L, Zhuang YZ, Zu X and Wang Y: APE1 Asp148Glu gene polymorphism and bladder cancer risk: A meta-analysis. Mol Biol Rep 40: 171-176, 2013.

47. Sweasy JB, Lang T and DiMaio D: Is base excision repair a tumor suppressor mechanism? Cell Cycle 5: 250-259, 2006.

48. Kunath F, Krause SF, Wullich B, Goebell PJ, Engehausen DG, Burger M, Meerpohl JJ and Keck B: Bladder cancer-the neglected tumor: A descriptive analysis of publications referenced in MEDLINE and data from the register ClinicalTrials.gov. BMC Urol 13: 56, 2013. 